\title{
GESTÃO DA QUALIDADE EM BIBLIOTECAS ESCOLARES: UM ESTUDO DE CASO EM UMA BIBLIOTECA ESCOLAR NA CIDADE DE PONTA GROSSA - PR
}

\author{
QUALITY MANAGEMENT IN SCHOOL LIBRARIES: A CASE STUDY IN A \\ SCHOOL LIBRARY IN THE CITY OF PONTA GROSSA - PR
}

\section{Josiane Mello $^{1}$}

Resumo: O presente relato faz uma reflexão a respeito da gestão da qualidade em bibliotecas escolares. Apresenta um estudo realizado em uma biblioteca escolar na cidade de Ponta Grossa - PR, com o objetivo geral de analisar as ações da gestão da qualidade existentes nesse ambiente, visando à melhoria contínua. Para alcance deste objetivo, utilizaram-se as ferramentas da qualidade: Diagrama causa - efeito e Plano de ação 5W2H. Para a coleta de dados fez-se uso de entrevistas com o quadro funcional da biblioteca, utilizou-se documentos administrativos e observação direta do ambiente estudado. Quanto aos procedimentos metodológicos, a pesquisa caracteriza-se como aplicada, qualitativa, com objetivos exploratórios e descritivos e procedimentos técnicos bibliográfico, documental e estudo de caso. Como resultados constatou-se que a biblioteca estudada já desenvolvia algumas ações da gestão da qualidade isoladamente, porém, faz-se necessário uma ação de melhoria no que refere-se ao baixo índice de utilização dos serviços ofertados bem como uma otimização no que se refere ao gerenciamento da biblioteca. Por fim, desenvolveu-se um plano de ação de melhorias, utilizando a ferramenta da qualidade $5 \mathrm{~W} 2 \mathrm{H}$, a fim de tornar a biblioteca uma unidade agregadora de valor.

\section{Palavras-chave}

Bibliotecas escolares. Gestão da qualidade. Melhoria contínua.

\begin{abstract}
This paper is a reflection on quality management in school libraries. Presents a study in a school library in the city of Ponta Grossa - PR, with the overall objective to analyze the actions of the existing quality management in this environment, aimed at continuous improvement. To reach this objective, we used the tools of quality: Diagram cause - effect, and plan of action 5W2H. For data collection was made use of interviews with the staff of the library, we used administrative documents and direct observation of the environment studied. As for methodological research procedures characterized from the point of view: its nature as applied, the qualitative approach to the problem, the objectives as exploratory and descriptive and technical procedures as bibliographical research and case study. The results are found, the library has developed some actions studied quality management alone, but it is necessary an improvement action in what refers to the low use of services offered as well as an optimization refers to the library management. Finally, we developed an improvement plan of action as the tool $5 \mathrm{~W} 2 \mathrm{H}$ quality in order to make the library unit accumulative value.
\end{abstract}

\footnotetext{
${ }^{1}$ Mestre em Engenharia da Produção na UFTPR; Especialista em Gestão de Bibliotecas Escolares; Bibliotecária da Biblioteca Central Zila Mamede da Universidade Federal do Rio Grande do Norte. Email: mellojosi@hotmail.com

Enviado em: 24/03/2012 - Aceito em: 16/12/2012.
} 


\section{Keywords}

School Library. Quality Management. Continuous Improvement.

\section{INTRODUÇÃO}

O ambiente organizacional está enfrentando desafios e incertezas, ocasionados pelas céleres mudanças de paradigma, pela qual a sociedade vem passando. Essas mudanças são oriundas da globalização da economia, forte impacto das tecnologias de informação e comunicação e da valorização dos ativos intangíveis.

Conforme Barbêdo (2004), a globalização da economia e, consequentemente, o aumento da competitividade entre as empresas define a qualidade como um fator essencial para a manutenção das organizações no mercado.

Para Feigenbaum (1994), em vista dos fatores envolvidos no gerenciamento da qualidade, a fim de, atender às exigências atuais de mercado, é essencial que organizações tenham um sistema definido e bem estruturado que identifique, documente, coordene e mantenha todas as atividades - chaves, necessárias para garantir as indispensáveis ações na qualidade ao longo de todas as operações relevantes.

Neste contexto, a qualidade assume o primeiro plano dentro das organizações, sendo a peça chave para assegurar a competitividade e existência das organizações no mercado, servindo como plano de fundo para o desenvolvimento de produtos (bens e /ou serviços) para uma sociedade cada vez mais exigente.

Isso não é diferente quando nos referimos às bibliotecas ou qualquer outra unidade de informação e documentação. No caso, das bibliotecas escolares, a qualidade se faz presente nestes espaços, tornando-as mais ativas, auxiliando eficazmente e com eficiência no processo ensino-aprendizagem, proporcionando a comunidade escolar valor agregado nos produtos (bens e /ou serviços) oferecidos.

Sob esta ótica, elegeu-se a biblioteca Escolar do Colégio Marista Pio XII de Ponta Grossa, para a realização desta pesquisa, com o objetivo geral de: analisar as ações da gestão da qualidade existentes neste espaço, visando à melhoria continua, e objetivos específicos: identificar ações da gestão da qualidade em uma biblioteca escolar; identificar os resultados relacionados à gestão da qualidade em uma 
biblioteca escolar e identificar limitantes e alavancadores das ações da qualidade em uma biblioteca escolar.

\section{CONTEXTUALIZAÇÃO DO PROBLEMA DE PESQUISA}

A escolha pela a biblioteca Escolar do Colégio Marista Pio XII de Ponta Grossa, para a realização desta pesquisa, ocorreu por dois motivos: sua importância para a comunidade escolar de Ponta Grossa, visto que a mesma ocupa um lugar de destaque na cidade, em comparação com as demais bibliotecas e ainda por apresentar características básicas de uma organização prestadora de serviço.

A educação é concebida apoiada em vários meios educativos. Um desses meios é sem dúvida a biblioteca, que "é o recurso indispensável para o desenvolvimento do processo ensino-aprendizagem e de suporte a programas educacionais". (CASTRO FILHO, 2008, p.73).

Sabe-se, que geralmente, é em fase escolar que a maioria das pessoas têm seu primeiro contato com a biblioteca, com os livros e com a leitura. Isso reforça a importância das bibliotecas escolares na sociedade atual, uma vez que estas têm como missão o desenvolvimento e à formação dos cidadãos "[....] críticos e efetivos usuários da informação, em todos os formatos e meios “[....]. (FEDERAÇÃO INTERNACIONAL DE ASSOCIAÇÕES DE BIBLIOTECAS E INSTITUIÇÕES, 1999, p. 1).

Assim, a biblioteca escolar deve ser organizada e gerenciada em função dos objetivos da escola, proporcionando o acesso a informações pertinentes ao desenvolvimento das atividades didático-pedagógicas, definidas no Projeto Político Pedagógico da escola.

Para que as bibliotecas escolares atinjam seus ideais, auxiliando no processo ensino-aprendizagem, a Federação Internacional de Associações de Bibliotecas e Instituições (IFLA), com a aprovação da Organização das Nações Unidas para a Educação, a Ciência e a Cultura (UNESCO), publicaram em 1999, um Manifesto para as Bibliotecas Escolares. Esse documento afirma que a biblioteca escolar deve:

\footnotetext{
- apoiar e intensificar a consecução dos objetivos educacionais definidos na missão e no currículo da escola;
} 
- desenvolver e manter nas crianças o hábito e o prazer da leitura e da aprendizagem, bem como o uso dos recursos da biblioteca ao longo da vida;

- oferecer oportunidades de vivências destinadas à produção e uso da informação voltada ao conhecimento, à compreensão, imaginação e ao entretenimento;

- apoiar todos os estudantes na aprendizagem e prática de habilidades para avaliar e usar a informação, em suas variadas formas, suportes ou meios, incluindo a sensibilidade para utilizar adequadamente as formas de comunicação com a comunidade onde estão inseridos;

- prover acesso em nível local, regional, nacional e global aos recursos existentes e às oportunidades que expõem os aprendizes a diversas idéias, experiências e opiniões;

- organizar atividades que incentivem a tomada de consciência cultural e social, bem como de sensibilidade;

- trabalhar em conjunto com estudantes, professores, administradores e pais, para o alcance final da missão e objetivos da escola;

- proclamar o conceito de que a liberdade intelectual e o acesso à informação são pontos fundamentais à formação de cidadania responsável e ao exercício da democracia;

- promover leitura, recursos e serviços da biblioteca escolar junto à comunidade escolar e ao seu derredor. (FEDERAÇÃO INTERNACIONAL DE ASSOCIAÇÕES DE BIBLIOTECAS E INSTITUIÇÕES, 1999, p. 2-3).

Para que esses objetivos sejam alcançados, faz-se necessário que a bibliotecas escolares sejam tratadas como organizações que fazem parte de um sistema. Sendo gerenciadas de forma eficiente, cujas funções administrativas: planejamento, organização, direção e controle estejam pautadas em um sistema de Gestão da Qualidade (SGQ) a fim de melhorarem seu desempenho bem como a qualidade dos produtos (bens e /ou serviços) oferecidos aos usuários.

Em solo brasileiro, observa-se ainda, salvo algumas exceções, que quando nas escolas existem espaços denominados de bibliotecas, estes são verdadeiros depósitos de materiais bibliográficos e objetos em geral.

Conforme apontado por Silva (1999, p.15),

às vezes, a "biblioteca" é um armário trancado, situado numa sala de aula, ao qual os alunos só têm acesso se algum professor se dispõe a abri-lo... quando a chave é localizada. Outras vezes, a biblioteca, razoavelmente instalada, funciona em horários breves e irregulares, sendo uma verdadeira loteria adivinhar quando ela estará aberta. Há situações em que o espaço da biblioteca escolar é utilizado não como lugar de estudo, de pesquisa ou de leitura, mas de punição: o aluno perde o recreio, ficando "de castigo" na biblioteca. E, na melhor das hipóteses, ou na menos pior, a biblioteca é o espaço onde os alunos vão copiar verbetes, trechos ou parágrafos dos mesmos livros e enciclopédias "recitados" pelos professores, "desde os tempos imemoriais...". Neste último caso, pelo menos há frequência e consulta à biblioteca, ainda que de forma acrítica e viciada. 
A partir da contextualização do problema de pesquisa, visando o alcance dos objetivos apresentados, formulou-se a seguinte questão de partida, norteadora deste trabalho:

Como analisar as ações da gestão da qualidade existentes em uma biblioteca escolar objetivando a melhoria contínua?

\section{A BIBLIOTECA ESCOLAR: CONCEITOS, CARACTERÍSTICAS E FUNÇÕES}

São muitas as visões que se tem da biblioteca escolar. Nas palavras de Silva (1999) e Romão (2008), para algumas escolas e autoridades, a biblioteca é um lugar que serve, para a guarda de cadeiras quebradas, trabalhos de arte em fase de secagem, artigos de festas de São João e inclusive livros.

Para outras escolas e autoridades, a biblioteca é o lugar ideal para acomodar alunos indisciplinados em sala de aula, para que estes copiem longas páginas de um livro. Tem ainda algumas escolas e autoridades, que fazem da biblioteca, um lugar de repouso profissional, onde são "encostados" professores por motivos de doença ou fastio pedagógico, até que a aposentadoria chegue (SILVA, 1999; ROMÃO, 2008).

Entretanto, têm pouquíssimas escolas e autoridades, que visualizam a biblioteca como um local prazeroso, que proporciona um encontro com a leitura, informação e o conhecimento, servindo de recurso fundamental para o processo de ensino-aprendizagem.

Essa mistura de visões cria uma confusão de identidade para a biblioteca escolar, assim, a maioria das pessoas e autoridades desconhece o real significado de uma biblioteca escolar e sua importância para o desenvolvimento da sociedade.

Nesta concepção, recorreu-se a literatura, fez-se um breve recorte teórico dos principais conceitos, características e objetivos das bibliotecas escolares, passando pelos conceitos proposto pelo Manifesto e pelas Diretrizes IFLA/UNESCO, publicados respectivamente, em 1999 e 2002, até chegar aos conceitos mais atuais, para este tipo de unidade de informação, conforme apresentados no quadro 1 a seguir: 


\section{Quadro 1}

Biblioteca escolar: conceitos, características e objetivos ${ }^{2}$

\begin{tabular}{|c|c|}
\hline Autor / Ano & Conceitos, Características e Objetivos \\
\hline OLIVEIRA $(1972$, p.193) & "[...] laboratório da pesquisa escolar" \\
\hline SANTOS $(1973$, p. 145) & $\begin{array}{l}\text { "[...] centro de informação e de cultura a serviço da } \\
\text { comunidade escolar." }\end{array}$ \\
\hline COSTA $(1975$, p. 278$)$ & $\begin{array}{l}\text { "[...] elemento de ligação entre o professor e aluno } \\
\text { na elaboração e apresentação de pesquisas..", } \\
\text { "[...] complemento às informações adquiridas em } \\
\text { classe..." }\end{array}$ \\
\hline CERDEIRA (1977, p. 36) & $\begin{array}{l}\text { "[...] centro de recursos educativos no qual a ênfase } \\
\text { não é apenas colocada na leitura, mas, igualmente, } \\
\text { em ouvir e observar materiais que compreendem } \\
\text { slides, transparências, filmes, diagramas, } \\
\text { reproduções de arte, fitas gravadas, etc." } \\
\text { "[...] um centro em que a interação do educando com } \\
\text { uma variada gama de recursos de comunicação os } \\
\text { transforma em verdadeiros laboratórios de auto- } \\
\text { aprendizagem." }\end{array}$ \\
\hline CARVALHO (1981, p. 28) & $\begin{array}{l}\text { "[...] principal centro de aprendizagem da escola, sob } \\
\text { atuação conjunta de professores e bibliotecários", } \\
\text { "[...] o desenvolvimento das potencialidades do } \\
\text { educando, prevendo suas necessidades intelectuais e } \\
\text { sociais e oferecendo-lhe meios de satisfazê-las } \\
\text { através de suas próprias indagações e pesquisas." }\end{array}$ \\
\hline QUEIROZ (1982) & $\begin{array}{l}\text { Elo entre a educação formal e a não formal, ou } \\
\text { permanente. }\end{array}$ \\
\hline LIMA (1982) & $\begin{array}{l}\text { A biblioteca escolar deve ter como função } \\
\text { principal permitir que se formem leitores, isto é: } \\
\text { indivíduos } \\
\text { capazes de reconhecer o valor da informação e } \\
\text { habilitados a utilizá-la. }\end{array}$ \\
\hline BARROSO (1984, p. 12) & $\begin{array}{l}\text { "[...] laboratório de aprendizagem integrado ao } \\
\text { sistema educacional, devendo facilitar o acesso, a } \\
\text { disponibilidade e a utilização de seus recursos a toda } \\
\text { a comunidade educacional." } \\
\text { "[...] oferece mecanismos concretos quanto ao } \\
\text { cumprimento das condições básicas do } \\
\text { desenvolvimento curricular", } \\
\text { "[...] adquirir uma especial importância quanto ao }\end{array}$ \\
\hline
\end{tabular}

${ }^{2}$ FONTE - Elaboração da autora, 2011. 


\begin{tabular}{|c|c|}
\hline & $\begin{array}{l}\text { desenvolvimento de atitudes, habilidades e deverá } \\
\text { ser um lugar convidativo, não importa o espaço que } \\
\text { ocupe, quão velho seja o mobiliário, pois não é } \\
\text { somente a aparência física que dá o clima de } \\
\text { biblioteca, e sim a imagem do bibliotecário, a qual a } \\
\text { biblioteca deve refletir" }\end{array}$ \\
\hline ANTUNES (1986) & $\begin{array}{l}\text { A biblioteca é o coração da escola. A biblioteca é o } \\
\text { coração do intelectual. Ambos são bons quando a } \\
\text { biblioteca deles é boa. A biblioteca é o sangue do } \\
\text { ensino. Ela é vital para o ensino e a educação dos } \\
\text { alunos e professores. É o computador do pensador, } \\
\text { do intelectualizante. É o cordão umbilical entre a } \\
\text { sala de aula e a aprendizagem da ministrância das } \\
\text { aulas. É o plasma do útero do conteúdo programático } \\
\text { de qualquer disciplina, e também é o plasma do } \\
\text { crescimento da curiosidade intelectual dos } \\
\text { educandos e dos educadores. }\end{array}$ \\
\hline CARVALHO (1986, p. 111) & $\begin{array}{l}\text { "[...] verdadeiro laboratório de aprendizagem dentro } \\
\text { da escola elementar" } \\
\text { "[...] lugar ideal para o impulso de busca - } \\
\text { descoberta da criança" } \\
\text { "[...] lugar de leitura ou, pelo menos, de leitura } \\
\text { recreativa, que sedimenta o hábito de ler e ajuda a } \\
\text { desenvolver, na criança, a imaginação e o } \\
\text { amadurecimento intelectual". }\end{array}$ \\
\hline RAMALHO (1988) & $\begin{array}{l}\text { A biblioteca escolar é desescolarizada; ir à biblioteca } \\
\text { significa, para a criança, em primeiro lugar mudar de } \\
\text { espaço, de atividade, e, em segundo a possibilidade } \\
\text { de desenvolver-se sem a pressão das exigências da } \\
\text { sala de aula. (ANTUNES apud RAMALHO, 1988). }\end{array}$ \\
\hline NERY (1989,p.56), & A biblioteca escolar é o centro do fazer educativo. \\
\hline BARBOSA (1991) & $\begin{array}{l}\text { Espaço vivo e atuante de que o usuário deve usufruir } \\
\text { em toda sua potencialidade, pois além de servir } \\
\text { como apoio no processo ensino aprendizagem, } \\
\text { constitui-se em lugar onde oportunidades de } \\
\text { experiência cultural podem ser criadas. }\end{array}$ \\
\hline $\begin{array}{l}\text { CASTRILLIÓN apud MAYRINK et al. (1992, } \\
\text { p. 49) }\end{array}$ & $\begin{array}{l}\text { Considera a biblioteca um instrumento de } \\
\text { desenvolvimento curricular que constitui parte } \\
\text { integral do sistema educativo, participando de seus } \\
\text { objetivos, metas e fins. } \\
\text { "[...] (a biblioteca) é uma instituição social que } \\
\text { organiza materiais bibliográficos e } \text { não } \\
\text { bibliográficos, colocando-os à disposição da } \\
\text { comunidade educacional, possibilitando a } \\
\text { aprendizagem permanente, o fomento da leitura, a } \\
\text { criatividade, a comunicação, a recreação, apoiando } \\
\text { os docentes na sua capacitação, fornecendo-lhes a } \\
\text { informação necessária para a tomada de decisões em } \\
\text { aula." }\end{array}$ \\
\hline
\end{tabular}




\begin{tabular}{|c|c|c|}
\hline RIBEIRO (1994) & $\begin{array}{l}\text { A biblioteca precisa ser entendida como um espaço } \\
\text { democrático, local de acesso crítico a informações. } \\
\text { Deve promover o encontro entre professor e aluno na } \\
\text { elaboração de leituras e pesquisas, servir de apoio } \\
\text { didático e cultural, apoiar informacionalmente o } \\
\text { professor e tornar-se um instrumento dinâmico e } \\
\text { eficaz no processo ensino-aprendizagem. }\end{array}$ & \\
\hline ESPAÑA (1995) & $\begin{array}{l}\text { A biblioteca escolar configura-se como um } \\
\text { elemento fundamental para estabelecer uma } \\
\text { verdadeira cultura de comunicação e } \\
\text { aprendizagem permanente nas escolas. }\end{array}$ & \\
\hline SANCHES NETO (1995) & $\begin{array}{l}\text { A biblioteca escolar que se queira eficaz tem que se } \\
\text { assumir como uma infinidade de janelas abertas para } \\
\text { o mundo e transmitir ao aluno o direito de escolha } \\
\text { por qual delas quer ele olhar. Os efeitos da leitura } \\
\text { não podem ser previamente definidos pelo educador. } \\
\text { Ler é sempre uma atividade cujos resultados são } \\
\text { imprevisíveis. }\end{array}$ & \\
\hline SILVEIRA (1996) & $\begin{array}{l}\text { A biblioteca escolar é uma das forças educativas } \\
\text { mais poderosas de que dispõem estudantes, } \\
\text { professores e pesquisador. O aluno deve investigar, e } \\
\text { a biblioteca é centro de investigação tanto como é } \\
\text { um laboratório. }\end{array}$ & \\
\hline RUEDA (1998) & $\begin{array}{l}\text { A biblioteca escolar deve ser um centro } \\
\text { de recursos que está organizado, eduque no uso de } \\
\text { distintas fontes de informação e documentação, } \\
\text { promova a autoaprendizagem, ajude na } \\
\text { formação leitora dos usuários (criando leitores } \\
\text { competentes na utilização de diversos tipos de } \\
\text { textos), promova a igualdade no acesso à leitura. }\end{array}$ & \\
\hline $\begin{array}{l}\text { FEDERAÇÃO INTERNACIONAL DE } \\
\text { ASSOCIAÇÕES DE BIBLIOTECAS E } \\
\text { INSTITUIÇÕES, }(1999, \text { p. } 2-3)\end{array}$ & $\begin{array}{l}\text { - apoiar e intensificar a consecução dos objetivos } \\
\text { educacionais definidos na missão e no currículo da } \\
\text { escola; } \\
\text { - desenvolver e manter nas crianças o hábito e o } \\
\text { prazer da leitura e da aprendizagem, bem como o } \\
\text { uso dos recursos da biblioteca ao longo da vida; } \\
\text { - oferecer oportunidades de vivências destinadas à } \\
\text { produção e uso da informação voltada ao } \\
\text { conhecimento, à compreensão, imaginação e ao } \\
\text { entretenimento; } \\
\text { - apoiar todos os estudantes na aprendizagem e } \\
\text { prática de habilidades para avaliar e usar a } \\
\text { informação, em suas variadas formas, suportes ou } \\
\text { meios, incluindo a sensibilidade para utilizar } \\
\text { adequadamente as formas de comunicação com a } \\
\text { comunidade onde estão inseridos; } \\
\text { - prover acesso em nível local, regional, nacional e } \\
\text { global aos recursos existentes e às oportunidades } \\
\text { que expõem os aprendizes a diversas idéias, } \\
\text { experiências e opiniões; } \\
\text { - organizar atividades que incentivem a tomada de } \\
\text { consciência cultural e social, bem como de } \\
\text { sensibilidade; } \\
\text { - trabalhar em conjunto com estudantes, } \\
\text { professores, administradores e pais, para o alcance }\end{array}$ & $\begin{array}{l}0 \\
5 \\
50\end{array}$ \\
\hline
\end{tabular}




\begin{tabular}{|c|c|}
\hline & $\begin{array}{l}\text { final da missão e objetivos da escola; } \\
\text { - proclamar o conceito de que a liberdade } \\
\text { intelectual e o acesso à informação são pontos } \\
\text { fundamentais à formação de cidadania responsável } \\
\text { e ao exercício da democracia; } \\
\text { - promover leitura, recursos e serviços da } \\
\text { biblioteca escolar junto à comunidade escolar e ao } \\
\text { seu derredor. }\end{array}$ \\
\hline HILLESLIEINI ; FACHIN (2000, p. 91) & $\begin{array}{l}\text { A biblioteca escolar é também elemento de ligação } \\
\text { entre professor e aluno na elaboração das leituras e } \\
\text { pesquisas, buscando sempre uma melhor } \\
\text { metodologia de transmissão do conhecimento, } \\
\text { influenciando o hábito da leitura e tornando o aluno } \\
\text { mais crítico. }\end{array}$ \\
\hline $\begin{array}{l}\text { FEDERAÇÃO INTERNACIONAL DE } \\
\text { ASSOCIAÇÕES DE BIBLIOTECAS E } \\
\text { INSTITUIÇÕES, }(2002, \text { p. } 1)\end{array}$ & $\begin{array}{l}\text { A biblioteca escolar propicia informação e ideias que } \\
\text { são fundamentais para o sucesso de seu } \\
\text { funcionamento na sociedade atual, cada vez mais } \\
\text { baseada na informação e no conhecimento. A } \\
\text { biblioteca escolar habilita os alunos para a } \\
\text { aprendizagem ao longo da vida e desenvolve sua } \\
\text { imaginação, preparando-os para viver como cidadãos } \\
\text { responsáveis. }\end{array}$ \\
\hline CALDEIRA $(2003$, p. 47) & $\begin{array}{l}\text { A biblioteca escolar visa proporcionar aos alunos } \\
\text { oportunidades de leitura intensa e autônoma, além de } \\
\text { incentivar a busca de informação para responder a } \\
\text { questionamentos e solucionar problemas. }\end{array}$ \\
\hline CAMPELLO (2005) & $\begin{array}{l}\text { A biblioteca escolar é um espaço por excelência para } \\
\text { promover experiências criativas de uso de } \\
\text { informação. }\end{array}$ \\
\hline FRAGOSO (2005, p 47) & $\begin{array}{l}\text { A biblioteca "é o coração da escola, concedendo vida } \\
\text { à comunidade escolar, uma vez que permanece em } \\
\text { constante sintonia com o processo pedagógico." }\end{array}$ \\
\hline MACEDO (2005) & $\begin{array}{l}\text { A biblioteca escolar possibilita que o aluno seja } \\
\text { formado como usuário da informação em passos } \\
\text { gradativos para buscar, entender, organizar, } \\
\text { interpretar, avaliar, utilizar e comunicar a } \\
\text { informação. Não significa que seja um processo de } \\
\text { aquisição somente de habilidades formais de busca } \\
\text { em catálogos e ferramentas eletrônicas, mas também } \\
\text { sirva de mola propulsora para mudança de atitude a } \\
\text { respeito da informação, do conhecimento, da } \\
\text { preparação do escolar para a resolução de problemas } \\
\text { e tomada de decisões. O que se espera é o } \\
\text { desenvolvimento do desejado espírito crítico e } \\
\text { criativo do estudante no decorrer da vida toda. }\end{array}$ \\
\hline KUHLTHAU (2006) & $\begin{array}{l}\text { A biblioteca escolar visa capacitar crianças e jovens } \\
\text { para acessar, avaliar e utilizar os diversos recursos } \\
\text { informacionais, em suportes impressos ou } \\
\text { eletrônicos. }\end{array}$ \\
\hline CAMPELLO, $(2008$, p. 7) & $\begin{array}{l}\text { A biblioteca escolar, mais do que um estoque de } \\
\text { conhecimentos, pode constituir-se em um espaço } \\
\text { adequado para desenvolver nos alunos o melhor } \\
\text { entendimento do complexo ambiente } \\
\text { informacional da sociedade contemporânea" }\end{array}$ \\
\hline FARIA e PERICÃO (2008, p.102) & $\begin{array}{l}\text { A biblioteca escolar aquela que serve à população } \\
\text { estudantil de instituições educativas como }\end{array}$ \\
\hline
\end{tabular}




\begin{tabular}{|c|c|}
\hline & $\begin{array}{l}\text { universidades, } \\
\text { institutos politécnicos, colégios, escolas e todas as } \\
\text { outras instituições que fazem parte delas ou lhes } \\
\text { estão associadas. }\end{array}$ \\
\hline CASTRO FILHO (2008, p. 73) & $\begin{array}{l}\text { A biblioteca escolar tem responsabilidades com a } \\
\text { auto-educação dos seus clientes, está presente na } \\
\text { ação pedagógica dos professores, e precisa ser ativa } \\
\text { a fim de atrair a toda a comunidade à qual a escola } \\
\text { está vinculada. }\end{array}$ \\
\hline RASCHE (2009, p. 52) & $\begin{array}{l}\text { A biblioteca escolar, basicamente, tem como função } \\
\text { dar suporte às atividades de ensino realizadas na } \\
\text { escola. Dessa forma, disponibiliza acervo } \\
\text { documental para o corpo docente e discente. Esse } \\
\text { acervo pode estar nos mais variados suportes } \\
\text { informacionais. } \\
\text { Quando a biblioteca é espaço de atividades de } \\
\text { formação de leitores, entra aí muito presente o fator } \\
\text { de letramento e a preocupação com o gosto pela } \\
\text { leitura. Neste cenário, a biblioteca é um lugar de } \\
\text { aconchego, do imaginário, do leitor que se quer } \\
\text { crítico e criativo. }\end{array}$ \\
\hline CHAGAS $(2010$, p.8) & $\begin{array}{l}\text { As bibliotecas escolares são organizações que fazem } \\
\text { parte de um sistema de informaçôes, capazes de } \\
\text { atender as necessidades informacionais de seus } \\
\text { usuários, sendo compostas por documentos que } \\
\text { passam por todo o ciclo documental. Para que esse } \\
\text { ciclo aconteça é necessário o gerenciamento dessas } \\
\text { unidades de forma eficiente, sendo consideradas } \\
\text { então, as quatro funções administrativas, a saber: o } \\
\text { Planejamento, a Organização, a Direção e o } \\
\text { Controle. }\end{array}$ \\
\hline
\end{tabular}

Diante do que foi apresentado, pode-se perceber que houve uma evolução no conceito de biblioteca escolar, porém, tais conceitos reforçam cada vez mais o que deve ser uma biblioteca escolar e, não o que elas são efetivamente (salvo algumas exceções).

\section{A BIBLIOTECA ESCOLAR COMO UM SISTEMA}

As bibliotecas escolares são sistemas que se relacionam com os sistemas externos. Tal interação promove influências para as organizações, bem como, para o sistema externo. No caso das bibliotecas escolares, um exemplo, de influência desta unidade de informação em um sistema externo, pode ser a "disseminação do conhecimento na sociedade" (VARVAKIS, p. 12, 2010).

Nesta concepção de visão sistêmica, a gestão dessas bibliotecas escolares deve ser pautada em um conjunto de documentos administrativos, para a coleta, 
gerenciamento e divulgação de informações. Tais como: formulários, manuais, regimentos, regulamentos, relatórios e etc. E ainda, a biblioteca escolar deve possuir um sistema de gestão da qualidade, a fim de garantir a qualidade de seus produtos (bens e/ou serviço) ofertados aos seus clientes.

\section{SISTEMA DE GESTÃO DA QUALIDADE - (SGQ)}

As organizações dos mais variados segmentos vêm adotando sistema de Gestão da Qualidade (SGQ) a fim de melhorarem seu desempenho bem como a qualidade dos produtos (bens e/ou serviço) ofertados aos seus clientes.

Não basta conhecer e aplicar os conceitos e princípios de gestão da qualidade. É preciso incorporá-los na organização. Assim, de acordo com Varvakis (2010, p. 43) "um sistema de gestão da qualidade contém as políticas, diretrizes, responsabilidades e princípios de gestão da qualidade adotados pela organização!"”.

Para se implantar um sistema de gestão da qualidade em uma organização, ou em uma biblioteca, faz-se necessário conhecer os requisitos para tal ação. Esses requisitos são especificados na norma ISO 9001:2000.

\section{A GESTÃO DA QUALIDADE E MELHORIA CONTÍNUA EM BIBLIOTECAS ESCOLARES}

No Brasil, de acordo com a literatura, os estudos a cerca da gestão da qualidade em bibliotecas ou centros de informação, começaram a doze anos, tendo como foco as bibliotecas universitárias.

Recentemente a questão da gestão da qualidade e melhoria continua em bibliotecas escolares vem sendo alvo de pesquisas pelos estudiosos da área, talvez, pela conscientização das pessoas, no que tange a importância da disseminação da informação na sociedade, ou pelo, fato de as bibliotecas serem uma organização prestadora de serviços.

Assim, as bibliotecas escolares para contribuírem de forma sistêmica no processo de ensino-aprendizagem da comunidade escolar precisam ser agregadoras de valor. Para isto, precisam buscar a melhoria continua em seus processos.

A busca pela melhoria continua ocorre por meio de uma ação sistematizada dos processos pelo gestor da biblioteca, identificando oportunidades de melhoria, 
identificando soluções ou formas de transformar essas oportunidades de melhoria em elementos que modifiquem o processo.

Essa constante melhoria nos processos fará com que os usuários percebam valor agregado nos serviços recebidos.

\section{PROCEDIMENTOS METODOLÓGICOS}

\section{Materiais e métodos}

O Universo desta pesquisa constitui-se da biblioteca escolar do Colégio Marista Pio XII, situado na cidade de Ponta Grossa, a população refere-se aos funcionários da referida biblioteca, e a amostra é constituída por: uma bibliotecária e uma auxiliar de biblioteca.

A pesquisa foi realizada no período entre novembro de 2010 a março de 2011, onde foram realizadas visitas para conhecimento do objeto de estudo e posterior definição e elaboração do instrumento de coleta de dados a ser empregado.

Para a coleta de dados, o instrumento empregado foi à entrevista com o quadro funcional da biblioteca e observação direta do ambiente.

A entrevista ocorreu amparada em um roteiro estruturado, levando em consideração seis aspectos, que fazem parte de um conjunto de oportunidade de melhorias, a saber: espaço físico, mobiliário e equipamentos, acervo, serviços oferecidos, pessoal e administração, com a finalidade de se obter um diagnóstico da biblioteca e priorizar as oportunidades de melhorias.

Neste sentido, identificaram-se as ações existentes da gestão da qualidade, identificaram-se problemas, buscou- se soluções ou formas de transformar essas oportunidades de melhoria em elementos que modificassem o processo, conforme apresentado no tópico que refere-se a discussão dos resultados.

\section{Caracterização da pesquisa}

Essa pesquisa caracteriza-se, de acordo com Gil (2009):

- Do ponto de vista da sua natureza: pesquisa aplicada, pois objetiva gerar conhecimentos para aplicação prática e dirigidos à solução de problemas específicos. 
- Do ponto de vista da abordagem do problema: pesquisa qualitativa, requerendo interpretação dos fenômenos e a atribuição de significados.

- Do ponto de vista dos objetivos: pesquisa exploratória e descritiva. Exploratória, visando proporcionar maior familiaridade com o problema com vistas a torná-lo explícito ou a construir hipóteses. E descritiva, pois visa descrever as características de determinada população ou fenômeno ou o estabelecimento de relações entre variáveis. Envolve o uso de técnicas padronizadas de coleta de dados: questionário e observação sistemática.

- Do ponto de vista dos procedimentos técnicos: pesquisa bibliográfica, documental e estudo de caso. Pesquisa bibliográfica, devido ter sido elaborada a partir de material já publicado, constituído principalmente de livros, artigos de periódicos e, atualmente, com material disponibilizado na Internet. Documental, porque foi elaborada a partir de documentos que não receberam tratamento analítico. E estudo de caso, por envolver o estudo profundo e exaustivo de um ou poucos objetos de maneira que se permita o seu amplo e detalhado conhecimento.

\section{APRESENTAÇÃO E DISCUSSÃO DOS RESULTADOS}

A pesquisa foi realizada, obedecendo às seguintes etapas:

- Conhecer a organização: nesta etapa, fez-se um diagnóstico da biblioteca, levando em consideração 6 aspectos, Espaço Físico, mobiliário e equipamentos, acervo, serviços oferecidos, pessoal e administração, com finalidade de conhecer as características, aspectos positivos e as oportunidades de melhorias, conforme apresentado no quadro 2, a seguir:

Quadro 2

Diagnóstico da biblioteca: características, aspectos positivos e as oportunidades de melhorias ${ }^{3}$

\begin{tabular}{|c|c|c|c|}
\hline \multicolumn{2}{|c|}{ Aspectos analisados } & Aspectos positivos & $\begin{array}{c}\text { Oportunidades de } \\
\text { melhorias }\end{array}$ \\
\hline \multirow{4}{*}{ Espaço Físico } & Localização & $\begin{array}{c}\text { Boa localização. Fica } \\
\text { alocada em local de } \\
\text { bastante circulação }\end{array}$ & \\
\cline { 2 - 4 } & Área disponível & Suficiente & \\
\cline { 2 - 4 } & Horário de funcionamento & Atende todos os turnos & Horário de \\
\hline
\end{tabular}

${ }^{3}$ FONTE: Elaboração da autora, 2011

\begin{tabular}{l|l|l|l|l|l|l|}
\hline (C) Rev. digit. bibliotecon. cienc. inf. & Campinas, SP & v.11 & n.1 & p.111-137 & jan./abr. 2013 & ISSN 1678-765X \\
\hline
\end{tabular}




\begin{tabular}{|c|c|c|c|}
\hline & & $\begin{array}{l}\text { em que o colégio } \\
\text { funciona. }\end{array}$ & $\begin{array}{c}\text { funcionamento da } \\
\text { biblioteca quase } \\
\text { coincide com o horário } \\
\text { das aulas. }\end{array}$ \\
\hline & $\begin{array}{l}\text { Ruído, umidade, } \\
\text { temperatura, iluminação, } \\
\text { rede elétrica, infra- } \\
\text { estrutura de informática. }\end{array}$ & Adequado & \\
\hline \multirow{7}{*}{$\begin{array}{c}\text { Mobiliário e } \\
\text { Equipamentos }\end{array}$} & $\begin{array}{c}\text { Quantidade de assentos } \\
\text { para usuários, de estantes } \\
\text { e armários para a guarda } \\
\text { de acervo }\end{array}$ & Suficiente & \\
\hline & $\begin{array}{c}\text { Postos de trabalho para a } \\
\text { equipe }\end{array}$ & & $\begin{array}{c}\text { Não dispõe de um } \\
\text { espaço reservado para a } \\
\text { bibliotecária } \\
\text { desenvolver as } \\
\text { atividades } \\
\text { administrativas }\end{array}$ \\
\hline & $\begin{array}{l}\text { Estado de conservação, } \\
\text { estética, funcionalidade, } \\
\text { tipo e dimensões }\end{array}$ & Adequado & \\
\hline & $\begin{array}{l}\text { Quanto aos equipamentos } \\
\text { existentes destinados aos } \\
\text { funcionários }\end{array}$ & $\begin{array}{l}\text { Os computadores são } \\
\text { novos e estão em } \\
\text { ótimo estado de } \\
\text { conservação }\end{array}$ & $\begin{array}{l}\text { A biblioteca dispõe de } \\
\text { apenas um computador } \\
\text { para a realização de } \\
\text { empréstimos, } \\
\text { devolução e reservas }\end{array}$ \\
\hline & $\begin{array}{c}\text { Quanto aos equipamentos } \\
\text { existentes destinados aos } \\
\text { usuários }\end{array}$ & $\begin{array}{c}\text { Os computadores são } \\
\text { novos e estão em } \\
\text { ótimo estado de } \\
\text { conservação. A } \\
\text { biblioteca dispõe de } \\
\text { cinco computadores } \\
\text { com acesso à internet }\end{array}$ & $\begin{array}{l}\text { A biblioteca dispõe de } \\
\text { apenas um terminal de } \\
\text { consulta ao acervo }\end{array}$ \\
\hline & Suporte de TI & $\begin{array}{l}\text { O Departamento de TI } \\
\text { é responsável pelo } \\
\text { Funcionamento e } \\
\text { atualização do } \\
\text { software de } \\
\text { gerenciamento da } \\
\text { biblioteca. Porém } \\
\text { alguns procedimentos } \\
\text { que são específicos do } \\
\text { Pergamum, abri-se } \\
\text { um chamado à PUC } \\
\text { (Responsável pelo } \\
\text { software) }\end{array}$ & \\
\hline & Tempo de espera & $\begin{array}{c}\text { Quando da solicitação, } \\
\text { a biblioteca é } \\
\text { prontamente atendida }\end{array}$ & \\
\hline \multirow[t]{2}{*}{ Acervo } & Pertinência e atualização & $\begin{array}{c}\text { Atualizado, ampla } \\
\text { cobertura das áreas de } \\
\text { conhecimento, dispõe } \\
\text { de ampla variedade de } \\
\text { suporte. }\end{array}$ & \\
\hline & $\begin{array}{c}\text { Formação e } \\
\text { desenvolvimento }\end{array}$ & $\begin{array}{c}\text { Dispõe de verbas para } \\
\text { a aquisição de } \\
\text { materiais }\end{array}$ & $\begin{array}{l}\text { Segue uma política de } \\
\text { desenvolvimento da } \\
\text { coleção padrão }\end{array}$ \\
\hline
\end{tabular}




\begin{tabular}{|c|c|c|c|}
\hline & & bibliográficos & $\begin{array}{l}\text { utilizadas para todas as } \\
\text { bibliotecas, não } \\
\text { contemplando a } \\
\text { realidade da referida } \\
\text { biblioteca. }\end{array}$ \\
\hline & $\begin{array}{l}\text { Aquisição de materiais } \\
\text { bibliográficos }\end{array}$ & $\begin{array}{l}\text { Investimento em } \\
\text { acervo }\end{array}$ & $\begin{array}{l}\text { Demora, pois todo } \\
\text { pedido vai para a } \\
\text { matriz para aprovação } \\
\text { e repasse de verbas }\end{array}$ \\
\hline & $\begin{array}{c}\text { Quanto ao software } \\
\text { utilizado }\end{array}$ & $\begin{array}{c}\text { Atende às } \\
\text { necessidades de } \\
\text { descrição dos } \\
\text { documentos e acesso à } \\
\text { informação. Atende } \\
\text { aos padrões } \\
\text { internacionais de } \\
\text { comunicação de dados }\end{array}$ & \\
\hline & Processamento técnico & $\begin{array}{c}\text { Segue padrões. É ágil } \\
\text { e racional }\end{array}$ & \\
\hline & Qualidade da indexação & $\begin{array}{l}\text { Utiliza vocabulário } \\
\text { controlado }\end{array}$ & \\
\hline & Acesso a informação & & $\begin{array}{l}\text { A biblioteca não dispõe } \\
\text { de um catalogo com } \\
\text { sites existentes com a } \\
\text { finalidade informativa } \\
\text { e educativa }\end{array}$ \\
\hline & $\begin{array}{l}\text { Recuperação da } \\
\text { informação }\end{array}$ & Rápida e precisa & \\
\hline \multirow{6}{*}{$\begin{array}{c}\text { Serviços } \\
\text { Oferecidos }\end{array}$} & $\begin{array}{c}\text { Direcionados às } \\
\text { necessidades dos usuários }\end{array}$ & $\begin{array}{c}\text { A biblioteca realiza } \\
\text { serviços direcionados } \\
\text { ás necessidades dos } \\
\text { usuários, mediante } \\
\text { agendamento de } \\
\text { horário } \\
\end{array}$ & \\
\hline & Divulgação & $\begin{array}{l}\text { São divulgados aos } \\
\text { usuários reais e } \\
\text { potenciais, por meio } \\
\text { da página da } \\
\text { biblioteca na internet }\end{array}$ & \\
\hline & Índice de utilização & & $\begin{array}{c}\text { É baixo o índice de } \\
\text { utilização dos serviços, } \\
\text { em média } 1100 \\
\text { empréstimos por mês; } \\
7 \text { reservas e } 3 \\
\text { empréstimos entre } \\
\text { bibliotecas }\end{array}$ \\
\hline & Avaliação & $\begin{array}{c}\text { A biblioteca faz } \\
\text { avaliação anual dos } \\
\text { serviços prestados }\end{array}$ & \\
\hline & $\begin{array}{l}\text { Necessidade de } \\
\text { informação }\end{array}$ & $\begin{array}{l}\text { As necessidades de } \\
\text { informação são } \\
\text { conhecidas, pois a } \\
\text { biblioteca trabalha } \\
\text { integrada com o corpo } \\
\text { docente } \\
\end{array}$ & \\
\hline & Treinamento de usuários & Os usuários recebem & É pouco divulgado \\
\hline
\end{tabular}




\begin{tabular}{|c|c|c|c|}
\hline & (visita orientada) & $\begin{array}{c}\text { orientação para } \\
\text { manusear os } \\
\text { equipamentos, utilizar } \\
\text { os recursos e serviços } \\
\text { que a biblioteca } \\
\text { dispõe. É oferecido } \\
\text { regularmente, sendo } \\
\text { sistematizado e } \\
\text { segmentado (por ano } \\
\text { letivo) }\end{array}$ & \\
\hline & Projetos & $\begin{array}{c}\text { A biblioteca dispõe de } \\
\text { verbas para a } \\
\text { realização de } \\
\text { projetos, cujos } \\
\text { materiais e kits são } \\
\text { fornecidos pela } \\
\text { Província (Matriz). Os } \\
\text { pais dos alunos são } \\
\text { convidados a } \\
\text { participarem do } \\
\text { projeto. O projeto é } \\
\text { padrão, todas as } \\
\text { bibliotecas da rede } \\
\text { Marista desenvolvem } \\
\text { o mesmo projeto. }\end{array}$ & \\
\hline & Avaliação & $\begin{array}{c}\text { A biblioteca faz } \\
\text { avaliação anual dos } \\
\text { serviços prestados. Os } \\
\text { serviços oferecidos } \\
\text { estão alinhados aos } \\
\text { objetivos da biblioteca }\end{array}$ & \\
\hline \multirow{3}{*}{ Pessoal } & $\begin{array}{l}\text { Número de funcionários, } \\
\text { Formação e Educação } \\
\text { continuada }\end{array}$ & $\begin{array}{c}\text { Formação compatível } \\
\text { com a função. A } \\
\text { Instituição oferece } \\
\text { oportunidades e } \\
\text { estímulos para a } \\
\text { educação continuada }\end{array}$ & $\begin{array}{l}\text { Poucos funcionários, } \\
\text { precisava de mais um } \\
\text { auxiliar de biblioteca }\end{array}$ \\
\hline & $\begin{array}{l}\text { Contratação de } \\
\text { funcionários }\end{array}$ & & $\begin{array}{c}\text { O bibliotecário não } \\
\text { participa do processo } \\
\text { seletivo dos } \\
\text { funcionários da } \\
\text { biblioteca }\end{array}$ \\
\hline & $\begin{array}{l}\text { Relacionamento da equipe } \\
\text { de trabalho }\end{array}$ & $\begin{array}{c}\text { Ótimo relacionamento } \\
\text { entre bibliotecária e } \\
\text { auxiliar de biblioteca }\end{array}$ & \\
\hline \multirow[t]{3}{*}{ Administração } & Modelo de gestão & $\begin{array}{c}\text { Participativa, apoiado } \\
\text { em normas e } \\
\text { procedimentos / } \\
\text { alguns manuais de } \\
\text { serviço }\end{array}$ & \\
\hline & $\begin{array}{c}\text { Localização da biblioteca } \\
\text { no organograma da } \\
\text { Instituição }\end{array}$ & $\begin{array}{c}\text { Próxima à alta } \\
\text { administração (ao } \\
\text { poder decisório da } \\
\text { Instituição) }\end{array}$ & \\
\hline & $\begin{array}{c}\text { Documentos } \\
\text { organizacionais }\end{array}$ & $\begin{array}{l}\text { O software gera } \\
\text { relatórios das } \\
\text { atividades }\end{array}$ & $\begin{array}{l}\text { Falta manuais e } \\
\text { fluxogramas de } \\
\text { serviços. } \mathrm{O}\end{array}$ \\
\hline
\end{tabular}




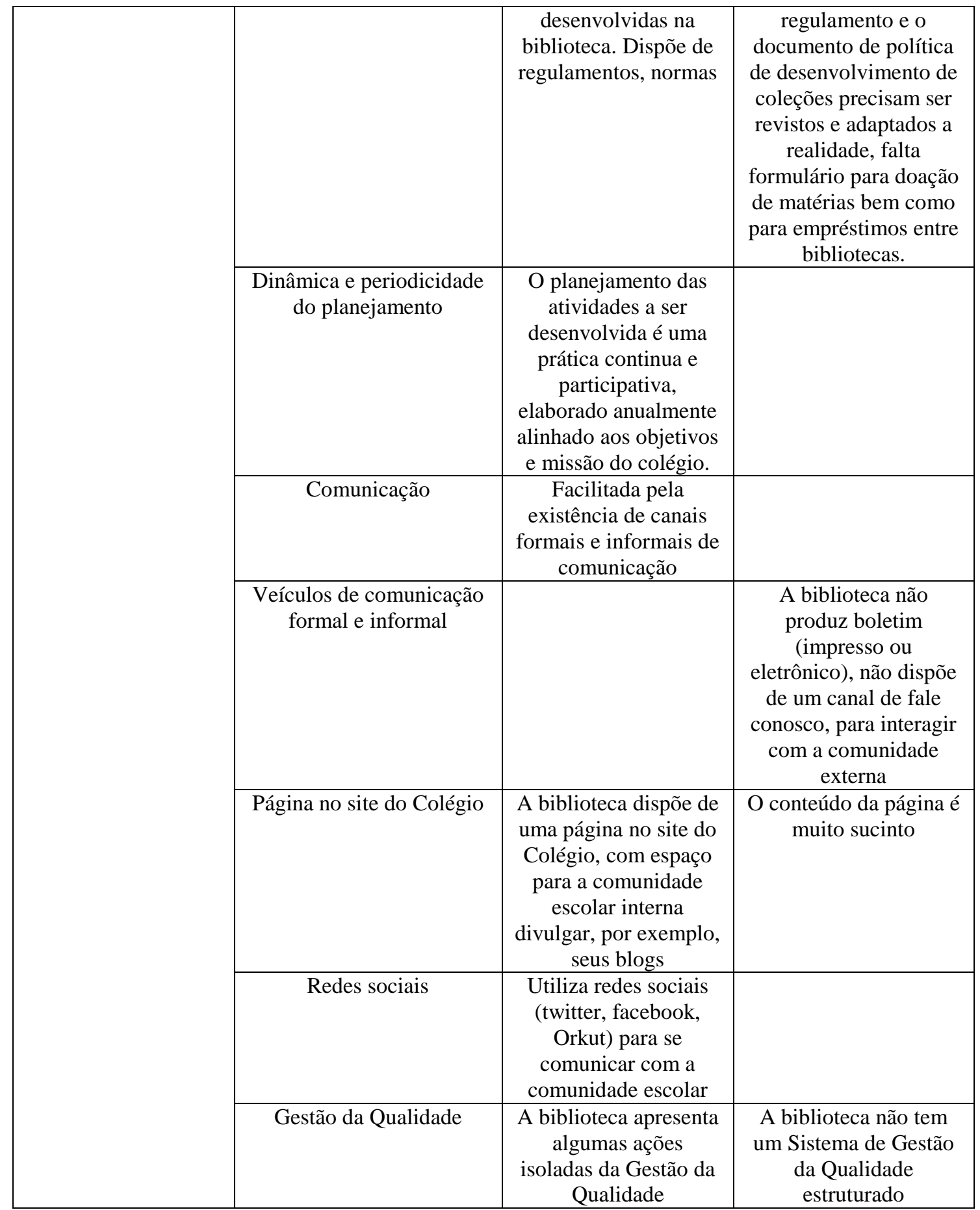

Com o diagnóstico, constatou-se, que a biblioteca já desenvolve algumas ações da gestão da qualidade, conforme descrito a seguir:

- A biblioteca tem foco no cliente: pois desenvolve suas atividades em consonância com as atividades pedagógicas estabelecidas pelos professores, visando o alcance dos objetivos propostos bem como a satisfação dos mesmos e, ainda 
interage com a comunidade interna e externa, por meio das redes sociais, buscando maior aproximação para identificar as necessidades de informação e expectativas em relação aos serviços. Observou-se ainda, que a biblioteca não dispõe de um processo de gestão das manifestações dos usuários.

- Quanto aos recursos humanos e liderança: a biblioteca dispõe de uma bibliotecária proativa e atenta as necessidades dos usuários, possui ainda, capacidade de delegar tarefas e envolver a equipe para o alcance de metas e objetivos propostos pelo Colégio.

A formação dos funcionários é compatível com a função desempenhada, o colégio ainda incentiva e promove cursos visando à educação continuada. Constatouse ainda, que a biblioteca dispõe de poucos funcionários, e, que com mais funcionários, a biblioteca pudesse desenvolver mais atividades, ou, ainda inovar nos serviços já existente.

Outra sugestão seria que a bibliotecária participasse do processo seletivo da contratação da equipe da biblioteca, pois ajudaria a selecionar um quadro funcional com o perfil necessário para atuar na biblioteca escolar.

- No que tange ao envolvimento de pessoas: verificou-se que existe um compartilhamento de conhecimentos e experiências entre os funcionários, informal (sem registro); a equipe de trabalho possui um ótimo relacionamento; participa nas decisões no que se refere aos serviços prestados pela biblioteca (Enfoque democrático), e tem clareza do que o colégio espera destes.

- Já no que concerne a abordagem de processo: as atividades de processamento técnico seguem padrões, utilizando vocabulário controlado para tornar a recuperação da informação rápida e precisa. Algumas atividades são desenvolvidas amparadas em documentos normativos, como por exemplo, o serviço de empréstimo é estabelecido pelo regulamento da biblioteca.

Cabe ressaltar ainda, que falta um documento de política de desenvolvimento de coleções voltado ao alcance dos objetivos da biblioteca. Quanto ao acervo, este é atualizado e amplo, cobrindo várias áreas do conhecimento, porém, embora o colégio preze pelo investimento em acervo, o processo é demorado, pois todo pedido passa pela aprovação da matriz para posterior repasse de verbas.

- Quanto à abordagem sistêmica: a equipe da biblioteca tem clareza de suas 
funções e responsabilidades.

- A melhoria contínua: está visível no planejamento anual que a biblioteca realiza das atividades que serão desenvolvidas ao longo do ano. No controle das despesas e dos custos, na obtenção de recursos, com solicitações baseadas em dados concretos.

Porém, falta aprimorar o processo de comunicação com a comunidade interna e externa, agregando valor às informações disponíveis na página da biblioteca, disponibilizando um canal de fale conosco; estabelecendo critérios palpáveis para a construção de uma política de desenvolvimento de coleções, tanto para o suporte físico quanto digital; elaboração de documentos, tais como formulários e manuais para padronizar e documentar as atividades realizadas, facilitando a comunicação entre os setores.

- Na abordagem factual para tomada de decisão: a biblioteca deixa a desejar neste quesito, devido não realizar estudos das necessidades dos usuários, nem processos gerenciais para identificar as falhas e propor mecanismos de prevenção e correção.

- Benefícios mútuos nas relações com os fornecedores de bens e serviços: a biblioteca tem um bom relacionamento com a matriz a qual está subordinada, possui um bom relacionamento com os fornecedores de livros da cidade, bem como com a equipe de suporte de Tecnologia da Informação.

- Identificar e priorizar os problemas: nesta etapa, após identificação dos problemas da biblioteca, priorizou-se apenas a análise dos seguintes problemas: baixo índice de utilização dos serviços da biblioteca e fragilidade no gerenciamento da biblioteca. Devido à solução desses problemas serem considerados simples e de baixo custo, e ainda, por estes problemas afetarem diretamente no alcance do principal objetivo da biblioteca, que é a eficiência no processo ensino-aprendizagem e o valor agregado nos produtos (bens e ou serviços) oferecidos a comunidade escolar. Tais problemas apresentam suas causas e efeitos, conforme figuras: 1 e 2 . 


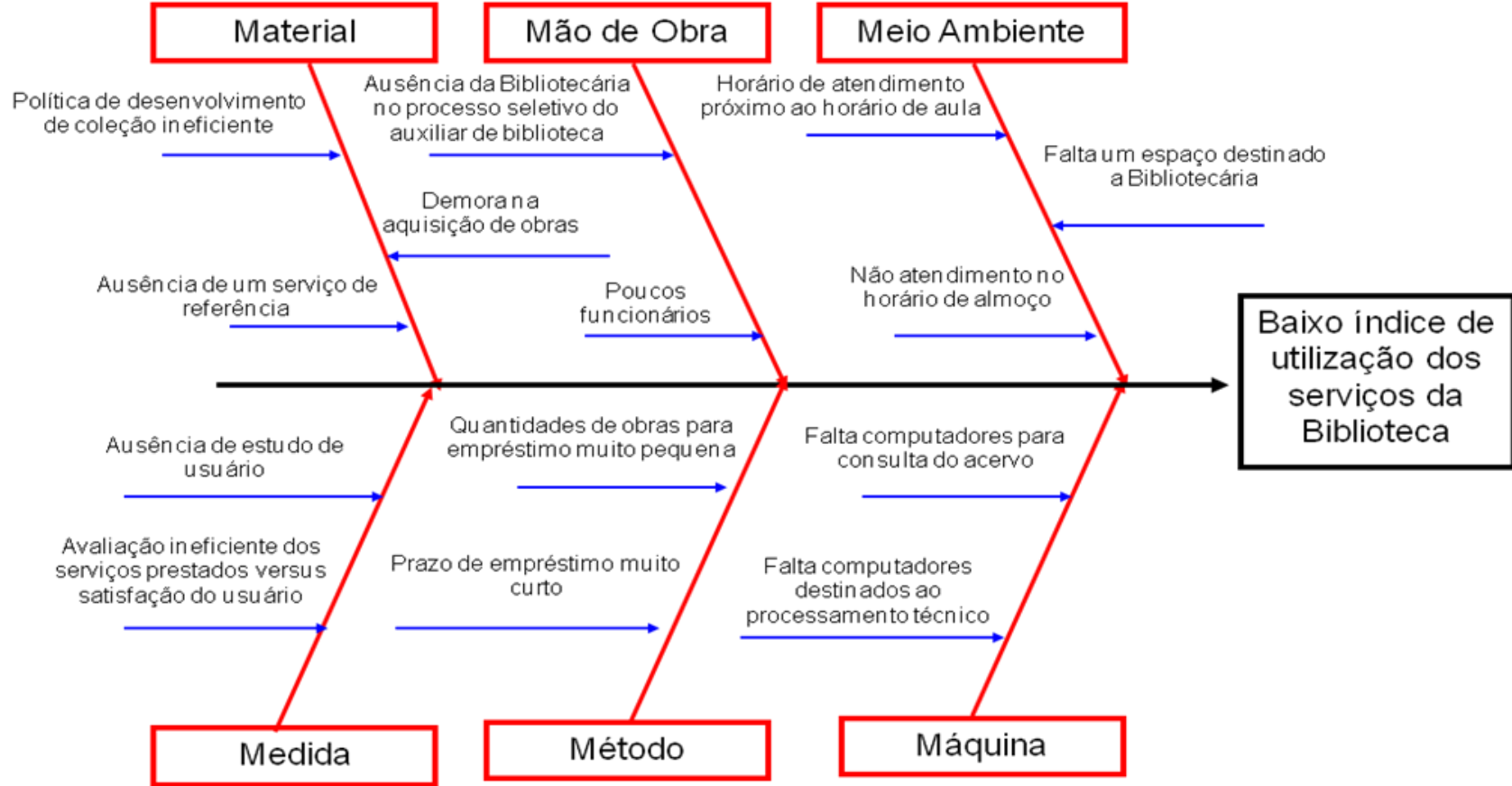

Figura 1 - Diagrama causa - efeito do baixo índice de utilização dos serviços da biblioteca $^{4}$

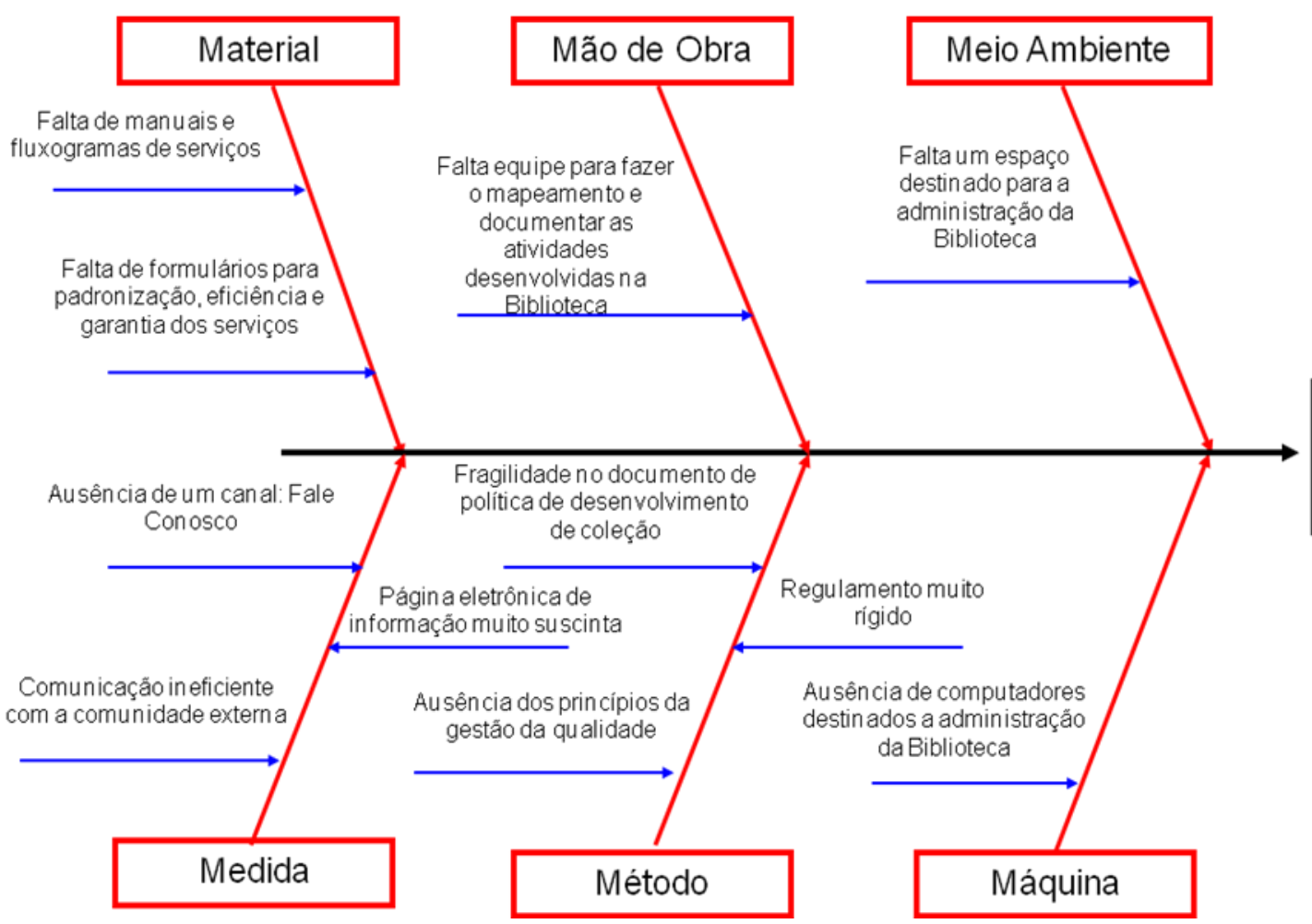

Fragilidade no gerenciamento da Biblioteca

Figura 2- Diagrama causa - efeito da fragilidade no gerenciamento da biblioteca ${ }^{5}$

${ }^{4}$ FONTE: Elaboração dos autores, 2011

${ }^{5}$ FONTE: Elaboração dos autores, 2011 
- Plano de ação: nesta etapa, após listar as possíveis causas de um problema, desenvolveu-se o seguinte plano de ação, visando à melhoria continua dos problemas apontados, na referida biblioteca. Utilizando a ferramenta da qualidade: Plano de ação $5 \mathrm{~W} 2 \mathrm{H}$.

\section{Quadro 3}

Plano de ação 5W2H - Baixo índice de utilização dos serviços da biblioteca ${ }^{6}$

\begin{tabular}{|c|c|c|}
\hline \multicolumn{3}{|r|}{ Plano de Ação } \\
\hline \multicolumn{3}{|c|}{ Objetivo: Aumentar o índice de utilização dos serviços da biblioteca } \\
\hline What? & O quê? & Aumento do índice de utilização dos serviços da biblioteca \\
\hline Why? & Por quê? & $\begin{array}{l}\text { Aumentar a satisfação dos usuários e permitir maior utilização da } \\
\text { biblioteca. Isso possibilitará que a biblioteca tenha mais argumentos } \\
\text { quando da solicitação de recursos humanos ou materiais. }\end{array}$ \\
\hline Who? & Quem? & Equipe da biblioteca \\
\hline Where? & Onde? & Na biblioteca \\
\hline When? & Quando? & \\
\hline How? & Como? & $\begin{array}{l}\text { - Divulgando os serviços existentes; } \\
\text { - Disponibilizando um canal fale conosco para maior interação com } \\
\text { a comunidade interna e externa; } \\
\text { - Realizando um estudo de usuário para descobrir suas reais } \\
\text { necessidades; } \\
\text { - Analisando o regulamento da biblioteca, bem como a quantidade e } \\
\text { prazos de obras para empréstimos; } \\
\text { - Disponibilizando mais equipamentos aos usuários para consulta ao } \\
\text { acervo; } \\
\text { - Realizando outras atividades educativas em parcerias com outros } \\
\text { colégios da região; } \\
\text { - Aumentando o quadro funcional da biblioteca; } \\
\text { - Fazendo acompanhamento e relatório final. }\end{array}$ \\
\hline How Much? & $\begin{array}{l}\text { Quanto } \\
\text { custa? }\end{array}$ & O custo será equivalente ao salário de mais dois funcionários \\
\hline $\begin{array}{c}\text { How } \\
\text { Measure? }\end{array}$ & $\begin{array}{c}\text { Como } \\
\text { medir? }\end{array}$ & $\begin{array}{l}\text { Comparando os relatórios de empréstimos gerados pelo próprio } \\
\text { software de gerenciamento da biblioteca antes e depois da aplicação do } \\
\text { Plano de ação. }\end{array}$ \\
\hline
\end{tabular}

\section{Quadro 4}

Plano de ação 5W2H - Fragilidade no gerenciamento da biblioteca ${ }^{7}$

\begin{tabular}{|l|c|l|}
\hline \multicolumn{3}{|c|}{ Plano de Ação } \\
\hline Objetivo: Otimizar o gerenciamento da biblioteca \\
\hline What? & O quê? & $\begin{array}{l}\text { Elaboração da documentação administrativa faltante na biblioteca e } \\
\text { análise da documentação existente }\end{array}$ \\
\hline Why? & Por quê? & Tornar a biblioteca uma agregadora de valor \\
\hline Who? & Quem? & Equipe da biblioteca \\
\hline Where? & Onde? & Na biblioteca \\
\hline When? & Quando? & \\
\hline
\end{tabular}

${ }^{6}$ FONTE: Adaptado de Varvakis (2010, p. 95).

${ }^{7}$ FONTE: Adaptado de Varvakis (2010, p. 95). 


\begin{tabular}{|l|c|l|}
\hline How? & Como? & - Realizando um mapeamento das atividades desenvolvidas; \\
& & $\begin{array}{l}\text { - Documentando as atividades desenvolvidas por meio de manuais e } \\
\text { fluxogramas de atividades; } \\
\end{array}$ \\
& $\begin{array}{l}\text { - Proporcionando um espaço destinado a equipe que realizará tais } \\
\text { atividades; } \\
\end{array}$ & $\begin{array}{l}\text { - Revisão do documento de política de desenvolvimento de coleções } \\
- \text { Fazendo acompanhamento e relatório final. }\end{array}$ \\
\hline How Much? & $\begin{array}{c}\text { Quanto } \\
\text { custa? }\end{array}$ & O custo será equivalente ao salário de mais dois funcionários \\
\hline How & $\begin{array}{c}\text { Como } \\
\text { Measure? }\end{array}$ & Fazendo análise do processo. \\
\hline
\end{tabular}

A partir do plano de Ação 5W2H, com base nos indicadores: baixo índice de utilização dos serviços da biblioteca e fragilidade no gerenciamento da biblioteca será possível o acompanhamento de melhorias, onde se pode verificar se a execução está em consonância com o planejado, com a aplicação de medidas de desempenho para identificar e corrigir desvios.

A ação para obtenção da melhoria contínua: não foi implementada, conforme previsto no objetivo deste trabalho. Assim, não foi possível acompanhar a implementação do plano proposto, bem como confirmar resultados dentro dos procedimentos, servindo como sugestão para trabalhos futuros.

\section{LIMITANTES E ALAVANCADORES DA QUALIDADE}

Quando da proposição de um plano de ação com vistas à melhoria continua, faz-se necessário a análise de limitantes e alavancadores da qualidade. Nessa visão, a biblioteca estudada, apresenta as seguintes limitantes e alavancadores da qualidade, conforme quadro 5:

\section{QUADRO 5}

Alavancadores e limitantes da qualidade ${ }^{8}$

\begin{tabular}{|l|l|}
\hline LIMITANTES DA QUALIDADE & ALAVANCADORES DA QUALIDADE \\
\hline Abordagem no processo & Foco no cliente \\
\hline $\begin{array}{l}\text { Compartilhamento de conhecimentos e } \\
\text { experiências }\end{array}$ & Recursos humanos \\
\hline Gestão da comunicação & Enfoque democrático \\
\hline Abordagem factual & Abordagem sistêmica \\
\hline $\begin{array}{l}\text { Falta de manuais e formulários para padronizar a } \\
\text { realização das atividades }\end{array}$ & $\begin{array}{l}\text { Benefícios mútuos nas relações com os } \\
\text { fornecedores de bens e serviços }\end{array}$ \\
\hline
\end{tabular}

\footnotetext{
${ }^{8}$ FONTE: Elaboração dos autores, 2011.
}

\begin{tabular}{l|l|l|l|l|l|l|}
\hline (C) Rev. digit. bibliotecon. cienc. inf. & Campinas, SP & v.11 & n.1 & p.111-137 & jan./abr. 2013 & ISSN 1678-765X \\
\hline
\end{tabular}


Assim, para que a biblioteca alcance êxito na aplicação de um sistema de gestão da qualidade, faz-se necessário que a mesma trabalhe os limitantes apontados no quadro anterior, mapeando as causas e efeitos desses problemas e estabelecendo um plano de ação para solucioná-los, fazendo uso da ferramenta 5W2H.

\section{CONSIDERAÇÕES FINAIS}

A gestão da qualidade está, aos poucos, cada vez mais presente no âmbito das unidades de informação, a fim de transformá-las em unidades agregadoras de valor.

Para que tais organizações sejam agregadoras de valor, faz-se necessário um bom gerenciamento de seus processos. Assim, a busca pela melhoria continua ocorre por meio de uma ação sistematizada dos processos pelo gestor da biblioteca, identificando oportunidades de melhoria, identificando soluções ou formas de transformar essas oportunidades de melhoria em elementos que modifiquem todo o processo.

Essa constante melhoria nos processos fará com que os usuários percebam valor agregado nos serviços recebidos.

Para alcance dos objetivos propostos nesta pesquisa, fez-se inicialmente um diagnóstico da biblioteca estudada, identificou-se e priorizaram-se os problemas e, por fim, fez-se uma proposta de um plano de ação, visando à melhoria continua dos problemas priorizados, conforme a ferramenta da qualidade $5 \mathrm{~W} 2 \mathrm{H}$.

Com base no diagnóstico obtido, observou-se a existência de algumas ações da gestão da qualidade, embora isoladas, tais atividades estão sendo desenvolvidas visando à melhoria continua dos processos da biblioteca para que os usuários percebam valor aos produtos (bens e/ou serviço) a eles ofertados.

Existem ainda, várias ações a serem implantadas, conforme sugerido no plano de melhorias, para que a referida biblioteca busque uma possível certificação da qualidade num futuro próximo. 


\section{REFERÊNCIAS}

ANTUNES, Walda de Andrade. Biblioteca e sistema de ensino. Boletim ABDF. Nova Série, Brasília, v. 9, n.2, p. 121-125, abr./jun. 1986.

BARBÊDO, S. A. D. Sistema de gestão da qualidade em serviços: estudo de caso em uma biblioteca universitária. 2004. Dissertação (Mestrado em Engenharia de Produção) - Programa de Pós Graduação em Engenharia de Produção, Universidade Federal de Itajubá, Itajubá-MG, 2004.

BARBOSA, Reni Tiago Pinheiro. Biblioteca escolar: estudo do usuário e animação de leitura. Releitura, Belo Horizonte, n. 1, p. 31-38, nov./dez. 1991.

BARROSO, Maria Alice. Um modelo flexível para a biblioteca escolar. Revista Brasileira de Biblioteconomia e Documentação, Brasília, v. 17, n. 1, p. 12-17, jan./ jul. 1984.

CALDEIRA, Paulo da Terra. O espaço físico da biblioteca. In: CAMPELLO,

Bernadete Santos. A biblioteca escolar: temas para uma prática pedagógica. 2.ed.

Belo Horizonte: Autêntica, 2003. 62 p. p. 47-50.

CAMPELLO, Bernadete. A competência informal na educação para o século XXI. In: . et al. A biblioteca escolar. Belo Horizonte: Autêntica, 2005. p. 09 -11.

CAMPELLO, Bernadete Santos et al. A biblioteca escolar: temas para uma prática pedagógica. 2.ed. Belo Horizonte: Autêntica, 2008.

CARVALHO, Maria da Conceição. Educação de usuário em bibliotecas escolares: considerações gerais. Revista de Biblioteconomia de Brasília, Brasília, v. 9, n. 1, p. 22-29, jan./jun. 1981.

CARVALHO, Maria da Conceição. Procura-se um espaço para a leitura nas bibliotecas escolares. Boletim ABDF. Nova Série, Brasília, v. 9, n. 2, p. 111-115, abr./jun. 1986.

CASTRO FILHO, Claudio Marcondes de. Os caminhos da biblioteca escolar. In: ROMÃO, Lucília Maria Sousa (Org.). Sentidos da biblioteca escolar. São Carlos: Alphabeto, 2008. p. 73-91.

CERDEIRA, Theodolindo. A biblioteca escolar no planejamento educacional.

Revista de Biblioteconomia de Brasília, Brasília, v. 5, n. 1, p. 35-43, jan./jun. 1977.

CHAGAS, Magda. Organização de bibliotecas escolares. Florianópolis:

CIN/CED/UFSC, 2010.

COLÉGIO MARISTA. Disponível em: http://www.marista.org.br/marista-pio-xiibiblioteca/D774/. Acesso: 30 mar. 2011. 
COSTA, Tarcilla Martins da. Biblioteca escolar do Centro Pedagógico da UFMG.

Revista da Escola de Biblioteconomia da UFMG, Belo Horizonte, v. 4, n. 2, p. 278282, set. 1975.

ESPAÑA. Ministério de Educación. La biblioteca escolar en El contexto de la reforma educativa. Madrid: MEC, 1995. (Educar en La sociedad de información. Serie Monografías, $\mathrm{n}^{\circ} 1$ ). Disponível em:

$<$ http://www.isftic.mepsyd.es/w3/recursos2/bibliotecas/html/01documar co.htm>. Acesso em: 21 set. 2009.

FARIA, Maria Isabel; PERICÃO, Maria da Graça. Dicionário do livro: da escrita ao livro eletrônico. São Paulo: Editora da USP, 2008.

FEDERAÇÃO INTERNACIONAL DE ASSOCIAÇÕES DE BIBLIOTECAS E INSTITUIÇÕES. Manifesto para as bibliotecas escolares. 1999. Disponível em: <http://www.bmferreiradecastro.com/documentos/Manifesto\%20para\%20a\%20Biblio teca\%20Escolar.pdf>. Acesso em: 10 abr. 2009.

FEDERAÇÃO INTERNACIONAL DE ASSOCIAÇÕES DE BIBLIOTECAS E INSTITUIÇÕES. Diretrizes da IFLA/UNESCO para a biblioteca escolar. 2002. Disponível em: <http://archive. ifla.org/VII/s11/pubs/SchoolLibraryGuidelinespt_BR.pdf $>$. Acesso em: 10 abr. 2009.

FEIGENBAUM, A. V. Controle da qualidade total. São Paulo: Ed. Makron Books, 1994.

FRAGOSO, Graça Maria. A bela adormecida precisa acordar. In: MACEDO, Neusa Dias de (org.) Biblioteca escolar brasileira em debate: da memória profissional a um fórum virtual. São Paulo : SENAC / CRB8, 2005. p. 46-50.

GIL, Antonio Carlos. Como elaborar projetos de pesquisa. 4.ed. São Paulo : Atlas, 2009.

HILLESLIEINI, Araci Isaltina de Andrade; FACHIN, Gleisy Regina Bories. Biblioteca escolar: relato de experiência. Revista ACB: Biblioteconomia em Santa Catarina, Florianópolis, v. 5, n.5, 2000.

LIMA. Lauro de Oliveira. A biblioteca escolar no contexto educacional brasileiro. In: SEMINÁRIO NACIONAL SOBRE BIBLIOTECAS ESCOLARES, 1., out. 1982, Brasília. Anais... Brasília: INL, CERLAL,UNB, 1982.

KUHLTHAU, Carol C. Como usar a biblioteca na escola: um programa de atividades para o ensino fundamental. Tradução e adaptação de Bernadete Santos Campello et al. 2. ed. Belo Horizonte: Autêntica, 2004. 303 p.

MACEDO, Neusa Dias de. (Org.). Biblioteca escolar brasileira em debate: da memória profissional a um fórum virtual. São Paulo: Senac, 2005. p.167-403. 
MAYRINK, Paulo Tarcísio; MORANDIN, Rosana Helena; VANALLI, Tereza Raquel. Avaliação de coleção da FDE em bibliotecas de escolas da região de Marília. Revista Brasileira de Biblioteconomia e Documentação, São Paulo, v. 25, n. 3/4, p. 49-59, jul./dez. 1992.

NERY, Alfredina. Biblioteca escolar: um jeito de ajeitar a escola. In: GARCIA, Edson Gabriel (Org.). Biblioteca escolar: estrutura e funcionamento. São Paulo: Loyola, 1989. p. 51-60.

OLIVEIRA, Alaide Lisboa de. Escola e Biblioteca. Revista da Escola de Biblioteconomia da UFMG, BeloHorizonte, v. 1, n. 2, p. 184-195, set. 1972.

QUEIROZ, Raimunda Augusta de. A biblioteca escolar e o seu papel no sistema educacional. Revista de Cultural UFES, Vitória, n. 22, p. 47-56, 1982.

RAMALHO, Maria Olinda Horta. O silêncio na biblioteca escolar: necessidade ou mito? Revista de Biblioteconomia e Comunicação, Porto Alegre, v. 3, p. 87-90, jan./dez. 1988.

RASCHE, Francisca. Políticas públicas para bibliotecas escolares. Florianópolis: CIN/CED/UFSC, 2009.

RIBEIRO, Maria Solange Pereira. Desenvolvimento de coleção na biblioteca escolar: uma contribuição a formação critica sócio-cultural do educando. Transinformação, Campinas, v.6, n.1/2/3, p.60-73, jan./dez. 1994.

ROMÃO, Lucília Maria Sousa (Org.). Sentidos da biblioteca escolar. São Carlos: alphabeto, 2008.

RUEDA, Rafael. Bibliotecas escolares: guía para el profesorado de educación primaria. Madrid: Narcea, 1998.

SANCHES NETO, Miguel. Desordenar uma biblioteca: comércio \& indústria da leitura na escola. Leitura: teoria \& pratica, Campinas, v.14, n.26, p.31-34, dez. 1995.

SANTOS, Inácia Rodrigues dos. A biblioteca escolar e a atual pedagogia brasileira. Revista de Biblioteconomia de Brasília, Brasília, v. 1, n. 2, p. 145-150, jul./dez. 1973.

SILVA, Waldeck Carneiro da. A miséria da biblioteca escolar. 2. Ed. São Paulo: Cortez, 1999.

SILVEIRA, Itália Maria Falceta da. Ensinar a pensar: uma atividade da biblioteca escolar. Revista de Biblioteconomia \& Comunicação, Porto Alegre, v.7, p.9-30, jan./dez. 1996.

VARVAKIS, Gregório. Gestão da qualidade dos serviços em bibliotecas escolares. Florianópolis: CIN/CED/UFSC, 2010. 
Como citar este relato:

MELLO, Josiane. Gestão da qualidade em bibliotecas escolares: um estudo de caso em uma biblioteca escolar na cidade de Ponta Grossa - PR. Rev. digit. bibliotecon. cienc. inf., Campinas, SP, v.11, n.1, p.111-137, jan./abr. 2013. ISSN 1678-765X. Disponivel em: $<$ http://www.sbu.unicamp.br/seer/ojs/index.php>. 